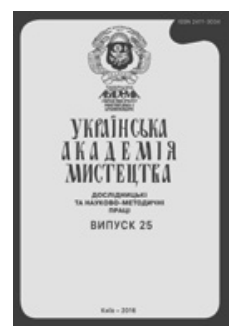

№27 (2018) стор. 99-104

The National Academy of Fine Arts and Architecture

Ukrainian Academy of Fine Art. Research and Methodology Papers

ISSN 2411-3034

Website: http://naoma-science.kiev.ua/

УДК 75.052(477)«195/199»

ORCID 0000-0002-3614-5426

DOI: https://doi.org/10.33838/naoma.27.2018.99-104

\title{
Віктор Григоров
}

аспірант кафедри теорії та історії мистецтвва НАОМА Науковий керівник професор М. Р. Селівачов

GrigorovVictor@gmail.com

\section{МОНУМЕНТАЛЬНО-ДЕКОРАТИВНЕ МИСТЕЦТВО ДРУГОЇ ПОЛОВИНИ ХХ СТ. У ФАХОВІЙ ЛІТЕРАТУРІ}

\begin{abstract}
Анотація. У статті розглядається коло питань, щчо висвітлюються в радянських та пострадянських дослідженнях монументального живопису у 1960-2000-х рр., та простежується розвиток мистеитвознавчої літератури протягом зазначеного періоду.
\end{abstract}

Ключові слова: монументальний живопис, мистецтвознавча література, друга половина ХХ ст.

МОНУМЕНТАЛЬНО-ДЕКОРАТИВНОЕ ИСКУССТВО ВТОРОЙ ПОЛОВИНЫ ХХ В. В ПРОФЕССИОНАЛЬНОЙ ЛИТЕРАТУРЕ.

Виктор Григоров

Аннотация. В статье рассматривается круг вопросов, которые отражены в научных роботах по монументальной живописи в 1960-2000 г2., прослеживается развитие искусствоведческой литературы на протяжении обозначенного периода.

Ключевые слова: монументальная живопись, искусствоведческая литература, вторая половина ХХ века.

\section{MONUMENTAL AND DECORATIVE ART OF THE SECOND HALF OF THE 20TH CENTURY IN SPE- CIALIZED LITERATURE.}

Viktor Hryhorov

Summary. The article deals with a number of issues highlighted in the research of monumental painting during the 1960-2000s, and follows the development of art studies literature during the specified period.

Ukrainian monumental painting during the second half of the 20th century evolved rather unequally, which affected the art criticism reflections. In the 1960's and 80's the active and dynamic development of monumental art took place. Research in this area also reached the peak of its popularity. For example, the article of I. Pronina contains a review of publications from 1973-1974, and the author brought the statistics indicating more than 200 works. (180)

Since the mid-1960's, academics have been increasingly focusing on monumental art. The attitude to monumental painting in the art history literature of the 1960's is ambiguous. However, most researchers are still critical of postwar practice and consider monumental works of the late 1950's and 1960's as a step forward.

The distinctive differences between the 1960's and 1970's - 1980's lie in various attitudes towards themes and scenes of the monumental painting. In the 1960's the monumentality was associated with the laconic content, using a set of all understandable associative attributes.

The expansion of the range of themes in monumental painting in the professional literature occured in the 1970's. Since the 
research problem stands at the crossroads of various branches of art, important scientific advancements were reflected in such prominent professional publications as: "Architecture of the USSR», «Decorative art of the USSR» and «Fine Arts». In the 1970's the publishing house "Soviet artist» released a series of articles compilations called «Soviet monumental art.» The state of monumentalism significantly changes in 1990's as there was a significant decline in the activity of this artistic direction. At this time the monumental painting fell into the field of wide-scale artistic studies.

In the professional literature of the last decade the scope of art study themes has changed to a certain extent as the art historians more often address the issues previously tabooed in Soviet times, and some of them partially or fully relate to the monumental painting. To such themes belong the Sixties and Boichukizm.

Today the problem of the preservation of Soviet monumental works sharply appears. Many authors turn to the theme of monumental art in order to attract the attention of society to the rapid destruction of mosaics and wall murals, and to prove their value for Ukrainian fine arts.

Key words: monumental painting, art criticism literature, second half of the 20th century.

Постановка проблеми. Фахова література другої половини XX ст. по-різному оцінює монументальний живопис. Деякі стилістичні особливості, що позитивно сприймаються в одне десятиліття, згодом стають негативними й навпаки. Це створює певні труднощі в систематизації й аналізі монументальних творів і самих досліджень. Практично в кожному десятилітті визначалися різні завдання у вивченні та теоретичному обгрунтуванні монументального живопису. I для виявлення сьогоднішньої загальної картини слід розкрити аспекти, характерні для кожного періоду.

Актуальність дослідження. Монументальне мистецтво минулого століття привертає увагу багатьох сучасних авторів. Різноманітні чинники, що загрожують фізичному існуванню стінописів та мозаїк другої половини XX ст. стають поштовхом для наукових досліджень і заснування різноманітних фондів, які сприяють захисту та систематизації монументального спадку. Різні проблеми монументального живопису вже було з'ясовано - тепер вони можуть лягти в основу нових наукових пошуків. Водночас саме огляд проблематики мистецтвознавчих розвідок дасть змогу виявити перспективні та недоопрацьовані раніше аспекти.

Аналіз останніх досліджень та публікацій. Сьогодні публікується чимало робіт, які у різних контекстах аналізують монументальний живопис другої половини XX ст. Проте досі бракує розвідок, у яких би структурувалась й аналізувалася відповідна фахова література. Так, наприклад, у статті Д. Шинкаренка (2010) «Монументальне мистецтво України 60-80-х років XX ст.: практика і теорія» розглянуто розвиток монументального живопису через призму тогочасних теоретичних розробок, увагу акцентовано на найбільш знакових роботах. Критичний огляд мистецтвознавчих досліджень радянського періоду зустрічаємо у публікації Т. Кочубинської «Киевские мозаики». Зокрема, автор вказує на низку праць, виданих у доперебудовчий період, у яких теми, сформульовані ще на початку розвитку радянського монументального живопису, спрощуються, перетворюючись на шаблонні та переносяться зі статті до статті (Кочубинська 310).

Новизна наукового дослідження. Автором уперше запропоновано простежити розвиток та виокремити характерні особливості фахової літератури за темою монументально-декоративного мистецтва другої половини XX ст.

Виклад основного матеріалу. Український монументальний живопис упродовж другої половини XX ст. розвивався доволі неоднорідно, що позначилося на мистецтвознавчих рефлексіях. У 60-80-х рр. відбувається динамічний розвиток монументального мистецтва. Дослідження у цій сфері сягають піку популярності. Приміром, у статті I. Проніної вміщено огляд публікацій за 1973-1974 рр., наведено статистику друкованих розвідок за вказаний період, а саме: «видано більше 200 праць 3 проблем теорії та практики сучасного радянського монументального мистецтва» (180). Вказані цифри ілюструють ситуацію, яка склалася на всесоюзному рівні, а стаття підтверджує особливу зацікавленість монументалістикою у цей період.

Становище монументалістики істотно змінюється у 1990-х рр., коли відбувається помітний спад активності цього художнього напрямку. Таку ситуацію зумовили різні чинники, зокрема: естетичні потреби суспільства, загальні тенденції в образотворчому мистецтві, але один із основних - матеріальна складова, оскільки монументалістика потребує значних фінансових 
ресурсів та виробничої бази. У 1990-х рр. вистачало художників-професіоналів, проте значно зменшилося фінансове забезпечення, що негативно вплинуло на розвиток монументального напрямку. За констатацією О. Авраменко, держава фактично монополізувала мистецький ринок 1960-1980-х рр. (197). А тим більше монументальний живопис, який щедро підтримувався й активно залучався до естетизації однотипної забудови та створення правильного ідейно-змістовного середовища. Водночас у кризові 90-ті відбувається переорієнтація монументального мистецтва зі сфери державних замовлень у приватний сектор.

Звичайно, залежно від ситуації мистецтвознавчі дослідження цього жанру здійснювалися в державі 3 різною інтенсивністю. Починаючи з середини 60-х рр. науковці дедалі білыше звертають увагу на монументалістику. До цього часу вже було створено ряд мозаїк та стінописів, в яких прочитувався свіжий підхід до образно-пластичної мови, що викликало зацікавлення у мистецтвознавців. Особливо жваве обговорення відбувалося довкола Київського річкового вокзалу, нового терміналу аеропорту «Бориспіль», Київського автовокзалу та інших об'єктів, які в подалышому стали зразком кращих витворів 60-х рр. Так, наприклад, мистецтвознавець і художник монументального мистецтва Б. Лобановський у статті «Аеровокзал в Борисполе» 3 певним захопленням аналізує мозаїки цього об'єкта.

У цей період виходять друком декілька загальних праць 3 історії українського образотворчого мистецтва, де автори окремо приділяють увагу монументальному мистецтву. Огляд монументального мистецтва на межі 50-60-х рр. зроблено науковцями В. Афанасьєвим та А. Шпаковим у дослідженні «Українське радянське мистецтво 1960-1980-х років». Ними позитивно оцінена відмова від помпезних розписів повоєнних років. Водночас відчувається певна обережність у судженнях щодо робіт, виконаних у 60-х рр. Зокрема, прагнучи досягнути синтезу монументального живопису із сучасними конструкціями архітектури, художники часто збіднювали свою творчість, зводячи все до схеми. (Афанасьєв, Шпаков 31)

Тоді ж виходить шостий том «Історії українського мистецтва», в якому Ю. Белічко, простежує особливості розвитку монументального живопису 1945-1967 рр. Варто зауважити, що науковець звертає увагу на позитивні зміни в монументальній практиці та доволі неоднозначно відгукується про роботи повоєнних років (Белічко 203). Ширший період охоплює монографія Б. Піаніди «Українське монументальне мистецтво», присвячена розвитку цієї галузі з 1917 р. до середини 60-х рр., огляду вибіркових творів вказаного періоду. На відміну від В. Афанасьєва та Ю. Белічка, Б. Піаніда оцінює післявоєнні та 50-ті рр. позитивно, зазначаючи що «реалістичні тенденції, ємність образів і змісту, епічність послужили основою для пошуків ще виразнішої форми монументальної мови мистецтва 60-х років» (33).

Як бачимо, ставлення до монументального живопису у мистецтвознавчій літературі 60-х рр. неоднозначне, проте більшість дослідників все ж критично підходять до післявоєнної практики, а монументальні твори кінця 50-60-х рр. вважають кроком уперед.

Характерними відмінностями між 60-ми та 70-80-ми роками є різне ставлення до тем і сюжетів стінопису. У 60-х монументальність асоціювалася 3 лаконічністю змісту, використанням набору всім зрозумілих асоціативних атрибутів. Наприклад, на розі будівлі кінотеатру «Україна» в Яготині в одному панно було зібрано цілу низку тривіальних образів: жіноча голова у вінку, голуби, ракета, квіти. Таке розмаїте наповнення здобуває схвальні відгуки у 60-х р. Зокрема, мистецтвознавець М. Пекаровський пише:

Чітко вираженими рисами монументальності відрізняється, наприклад, керамічне панно на фасаді кінотеатру «Україна» в Яготині. Тут показаний символічний образ України, досягнення радянського народу у завоюванні космосу. (10)

Згодом такий підхід різко критикують. А. Ревенко вже у 1978 р. зауважує, що «використання символічних атрибутів, формально поєднаних між собою, які не несуть великого смислового навантаження, не має права на життя» (85).

Також у 70-80-х рр. в роботах деяких авторів можна простежити зміни у поглядах. Наприклад, вже згадуваний нами В. Афанасьєв, у пізнішій роботі, присвяченій українському мистецтву 1960-1980-х рр., розглядає монументальний живопис у трохи піднесеній формі, загалом оцінюючи його позитивно, зауважуючи, що «саме протягом розглядуваного часу монументально-декоративне мистецтво зазнало значної еволюції і набуло своєрідної автономності» (67).

Розширення кола питань 3 монументального живопису у фаховій літературі відбувається в 70-х рp. Оскільки досліджувана проблематика перебуває 
на перехресті різних галузей мистецтва (особливо тісний взаємозв'язок 3 архітектурою), важливі наукові розвідки знаходимо на сторінках таких спеціалізованих видань, як: «Архитектура СССР», «Декоративное искусство СССР», «Образотворче мистецтво». У 70-х рр. видавництво «Радянський художник» випускає цикл збірників статей «Радянське монументальне мистецтво», в якому публікації структуруються за темами. Це ще раз підтверджує велику увагу до монументалістики в цей період.

Практично в усіх статтях за 70-80-ті рр. автори так чи інакше звертаються до теми синтезу мистецтв. Однак зауважимо, що не у всіх дослідженнях правильно трактується це поняття. Іноді, розглядаючи стінописи чи мозаїки, автори називають синтезом мистецтва вдале розміщення монументальних творів в архітектурній ситуації. Хоча вказане поняття передбачає складнішу взаємодію.

Синтез - це нерозривне, нероздільне поєднання, це така злитість компонентів, коли всі вони разом утворюють нове явище, що радикально відрізняється від своїх складових частин. (Лебедєва 3)

Стінопис розглядають як важливий елемент у формуванні не лише окремих будівель, а й цілих архітектурних ансамблів уже наприкінці 60-х рр. Згодом розроблення цілісних архітектурних ансамблів трансформується у створення загальноміських концепцій, в рамках якого, як зазначає С. Базазьянц, виникає термін «формування середовища», що включає не лише архітектуру та монументальний живопис, а й природу, техніку, історичні пам'ятки (17). Особливу увагу питанню місця монументального живопису в формуванні міського середовища приділяють наприкінці 80-х рр. З’являється чимала кількість публікацій на цю тему. Однією з найгрунтовніших є монографія Г. Скляренко «Мистецтво і місто» (1987), в якій досліджені й осмислені завдання монументального живопису в формуванні художнього образу міста на прикладі вже створених об’єктів у Києві та поза його межами.

Варто зауважити, що в радянський період у контексті синтезу мистецтв часто проводяться дослідження на межі архітектурного планування та монументального мистецтва. Як приклад можна навести статтю Ф. Уманцева «Торцы в современной застройке города», де мистецтвознавець розглядає принципи планування фасадів та торців будівель у формуванні міського простору. Одним із ефектних прийомів створення виразних торців, на думку автора, є монументальний живопис, однак лише за умови розуміння специфіки розміщення та взаємодії площини торцевої стіни з навколишнім середовищем (Уманцев 23).

Ще однією темою у роботах 70-80-х рр. стають народні традиції та національна своєрідність. Якщо в 60-х рр. просто схвалювали застосування типових асоціативних атрибутів, то пізніше питання національного змісту в монументальному живописі розглядається значно глибше. Цій проблематиці приділяла чимало уваги Н. Велігоцька. У спільній роботі Н. Велігоцької, А. Жиздринської та М. Коломійця «Монументально-декоративное искусство в архитектуре Украины» цілий розділ присвячено національній своєрідності. Автори формулюють особливості національної форми в монументально-декоративному мистецтві:

На наш погляд їй притаманні цільність композиційної структури, перевага живописної структури над «рисувальною», однак при збереженні чіткого ритмічного ходу, орнаментальні рамки, включення до композиції написів. (Велигоцкая, Жиздринская та Коломиец 97)

Значний внесок у дослідження монументального живопису зробила художниця та мистецтвознавець Л. Жоголь. У різні роки вона звертається до питання взаємодії інтер'єру та мистецтва. Слід звернути увагу на те, що чимало досліджень авторки присвячені саме декоративним аспектам цього явища.

У роки незалежності монументальний живопис потрапляє в поле широких загальномистецьких досліджень. Так, наприклад, Г. Скляренко у роботах 8090-х рр. глибоко досліджує тему монументалістики, торкаючись різних її аспектів, а з 2000-х рр. вже розглядає монументальний живопис крізь призму часу як етап розвитку всього візуального мистецтва.

У 90-х рр. художник-монументаліст постає перед складними проблемами. Якнайкраще ситуацію невизначеності, що склалася навколо монументального живопису упродовж 90-х рр., висвітлює мистецтвознавець 3. Чегусова у статті «Бути чи не бути?».

У фаховій літературі останніх десятиліть коло тем мистецтвознавчих досліджень певною мірою змінюється: мистецтвознавці звертаються до питань, табуйованих у радянський час, деякі з них частково або повною мірою стосуються монументального живопису. До таких можна зарахувати шістдесятництво та бойчукізм.

Тема шістдесятників та монументальний живопис 
60-х рр. пов'язані безпосередньо, адже багато митців-шістдесятників звертаються до стінопису, враховуючи його декоративно-формальні ознаки. У рамках шістдесятництва варто виокремити спеціальні дослідження творчості художників цього напряму; у їхньому доробку чимало вартісних творів монументального живопису. До таких належать дослідження життєвого та творчого шляху В. Зарецького та А. Горської. У монографії Л. Медведєвої «Віктор Зарецький. Митець, рокований добою» монументальній творчості художника присвячено цілий розділ, що спирається на його спогади та листування, в якому розкрито процес творчих пошуків та вагань митця у період роботи над монументальними панно.

Останнім часом монументальний живопис вивчають через призму персоналій. Проте тут відчутна деяка неоднорідність: існує чимало публікацій про творчість одних митців, тоді, як інші залишаються практично поза увагою, хоча вони також зробили вагомий внесок у монументально-декоративне мистецтво.

Сьогодні гостро постає проблема збереження радянських монументальних творів. Чимало авторів звертаються до теми монументального мистецтва, щоб привернути увагу суспільства до швидкої руйнації мозаїк та стінописів, обгрунтувати їхню цінність для українського образотворчого мистецтва. Серед таких публікацій варто згадати статтю Д. Шинкаренка «Зберегти в ім'я майбутнього», а також альбом «Decommunized: ukrainian soveti mosaics», де зібрано велику кількість фотографій радянських мозаїк з різних куточків України. Автор альбому Ю. Нікіфоров саме прагнув розкрити тему збереження цієї культурної спадщини.

Висновки. Отже, мистецтвознавча література свого часу по-різному оцінювала монументальне мистецтво. Так і завдання, що ставились перед монументальним живописом, відрізнялися у різні десятиліття. Проаналізувавши публікації другої половини ХХ ст., можемо відзначити різну інтенсивність дослідження монументального живопису; найбільший сплеск цього процесу припадає на 70-80-ті pр. Зауважимо, що у 80-х рр. дослідження монументалістики попередніх десятиліть постало перед цілою низкою раніше невирішених проблем.

Складність структуралізації полягає в тому, що дуже часто у рамках однієї роботи автори звертаються до цілого комплексу питань. Але відзначимо, що все ж у кожному дослідженні прослідковується основна тема. Наприклад, мистецтвознавчу літературу можна класифікувати за тематикою таким чином: розробка теми синтезу мистецтва, дослідження народних традицій та національної своєрідності у монументальному живописі, проблема взаємовідношень архітектора та художника, звернення до самих монументальних творів, адже часто дослідники розділяють монументальне мистецтво на те, що знаходиться в інтер'єрі, і на те, що перебуває в екстер'єрі. Враховуючи це, можна сказати, що праці не зводилися лише до проблематики монументального мистецтва, а містили значно ширший аналіз цього явища.

\section{Цитовані праці}

Авраменко, Олеся. «Зміни парадигми функціонування образотворчого мистецтва в Україні 1950-2005-х років». Нариси з історії образотворчого мистецттва України ХХ століття. В 2-х T. 2. Київ: Інтертехнологія, 2006. 193-239. Друк.

Афанасьєв, В. Українське радянське мистецтво 1960-1980-х років. Київ: Мистецтво, 1984. Друк.

Афанасьєв, В., Шпаков, А. Українське радянське мистецтво 1956-1965 років. Київ: Мистецтво, 1966. Друк. Базазяънц, Стелла. «Стелла Базазяънц - Украинские монументалисты: от количества к качеству». Декоративное искусство СССР 5 (1978): 14-23. Печать.

Белічко, Юрій. «Монументальний живопис». Історія українського мистецтва в 6-и т. Т. 6: Радянське мистецтвво 1941-1967 років. Київ: Жовтень, 1968. 185-203. Друк.

Велигоцкая, Н., А. Жиздринская, та Н. Коломиец. Монументально- декоративное искусство в архитектуре Украины. Киев: Будивельник, 1989. Печать.

Кочубинская, Татьяна. «Киевские мозаики» Искусство украинских шестидесятников. Сост. О. Балашова, Л. Герман. Киев: Основи, 2015. 308-315. Печать.

Лебедева, В. Советское монументальное искусство шестидесятых годов. Москва: Наука, 1973. Печать. Лобановский, Борис. Аэровокзал в Борисполе Декоративное искусство СССР 10 (1965): 5-7. Печать. 
Пекаровский М. Монументально-декоративное искусство в архитектуре общественных зданий. Москва, 1968. Печать.

Піаніда, Борис. Українське монументальне мистецтво. Київ, 1970. Друк.

Пронина, И. «Обзор советской литературы по монументальному искусству за 1973-1974 годы». Советское монументальное искусство 74 (1976): 180-187. Печать.

Ревенко, Алла. «Шляхи вирішення синтезу і втілення життєвої правди в українському монументальнодекоративному мистецтві». Мистецтвво і життя (1978): 82-94. Друк.

Уманцев, Ф. «Торцы в современной застройке города (на примере настройки Киева)». Архитектура СCCP 7 (1974): 22-25. Печать.

Чегусова, Зоя. «Бути чи не бути? Про минуле та майбутнє монументально- декоративного мистецтва України». Образотворче мистецтво 1 (1998): 30-33. Друк.

Шинкаренко, Дмитро. «Монументальне мистецтво України 60-80-х років XX ст.: практика і теорія». Українська академія мистецтва: дослід. та наук.-метод. пр. Спецвипуск: ФтіМ 50 років (2010): 367-370. Друк.

Nikiforov, Y. Decommunized: ukrainian soveit mosaics. Kyiv: Osnovy, 2017. Print.

\section{References}

Afanasjjev, V. Ukrajinsjke radjansjke mystectvo 1960-1980-kh rokiv. Kyjiv: Mystectvo, 1984. Druk.

Afanasjjev, V., Shpakov, A. Ukrajinsjke radjansjke mystectvo 1956-1965 rokiv. Kyjiv: Mystectvo, 1966. Druk.

Bazazya'nts, Stella. «Stella Bazazya'nts - Ukrainskie monumentalistyi: ot kolichestva k kachestvu». Dekorativnoe iskusstvo SSSR 5 (1978): 14-23. Pechat.

Belichko, Jurij. «Monumentaljnyj zhyvopys». Istorija ukrajinsjkogho mystectva v 6-y t. T. 6: Radjansjke mystectvo 1941-1967 rokiv. Kyjiv: Zhovtenj, 1968. 185-203.

Veligotskaya, N., A. Zhizdrinskaya, ta N. Kolomiets. Monumentalno-dekorativnoe iskusstvo $v$ arhitekture Ukrainyi. Kiev: Budivelnik, 1989. Pechat.

Kochubynskaja, Tatjjana. «Kyevskye mozayky» Yskusstvo ukraynskykh shestydesjatnykov. Sost. O. Balashova, L. Gherman. Kyev: Osnovy, 2015. 308-315. Pechatj.

Lebedeva, V. Sovetskoe monumentalnoe iskusstvo shestidesyatyih godov. Moskva: Nauka, 1973. Pechat.

Lobanovskiy, Boris. Aerovokzal v Borispole. Dekorativnoe iskusstvo SSSR 10 (1965): 5-7. Pechat.

Pekarovskiy, M. Monumentalno-dekorativnoe iskusstvo v arhitekture obschestvennyih zdaniy. Moskva, 1968. Pechat. Pianida, Borys. Ukrajinsjke monumentaljne mystectvo. Kyjiv: T-vo kuljturnykh zv’jazkiv z ukrajincjamy za kordonom, 1970. Druk.

Pronina, I. «Obzor sovetskoy literaturyi po monumentalnomu iskusstvu za 1973-1974 godyi». Sovetskoe monumentalnoe iskusstvo 74 (1976): 180-187. Pechat

Revenko, Alla. «Shljakhy vyrishennja syntezu i vtilennja zhyttjevoji pravdy v ukrajinsjkomu monumentaljnodekoratyvnomu mystectvi». Mystectvo i zhyttja (1978): 82-94. Druk.

Umantsev, F. «Tortsyi v sovremennoy zastroyke goroda (na primere nastroyki Kieva)». Arhitektura SSSR 7 (1974): 22-25. Pechat.

Cheghusova, Zoja. «Buty chy ne buty? Pro mynule ta majbutnje monumentaljno-dekoratyvnogho mystectva Ukrajiny». Obrazotvorche mystectvo 1 (1998): 30-33. Druk.

Shynkarenko, Dmytro. «Monumentaljne mystectvo Ukrajiny 60-80-kh rokiv XX st.: praktyka i teorija». Ukrajinsjka akademija mystectva: doslid. ta nauk.- metod. praci: Specvypusk: FtiM 50 rokiv (2010): 367-370. Druk.

Nikiforov, Y. Decommunized: ukrainian soveit mosaics. Kyiv: Osnovy, 2017. Print.

Подано до редакиії 26.11.2018

Рецензенти:

Кара-Васильєва Т. В. - доктор мистецтвознавства, академік;

Селівачов М. Р. - доктор мистецтвознавства, професор. 